\title{
Medical practice in Graeco-Roman antiquity
}

\author{
L Cilliers
}

Dept. of English and Classical Languages, University of the Free State

FP Retief

Honorary Research Fellow, University of the Free State

Keywords : Hippocratic medical practice Alexandrian/Hellenistic medical practice Roman medical care Military medicine Medicine in Roman North Africa Hospitals in antiquity

\section{Correspondence address:}

\section{Prof L Cilliers}

Faculty of the Humanities

Dept of English and Classical Languages

University of the Free State

POBox 339

Bloemfontein

9300

Tel : (051) 401-2303

Fax : (051) 444-5803

E-mail : cilliers.hum@mail.uovs.ac.za

\section{Abstract: Curationis 29(2): $34-40$}

The roots of modern medicine can be traced back to the $5^{\text {th }}$ century BC when Hippocratic rational medicine originated on the Greek islands of Cos and Cnidos. In this study we examine the way in which practitioners conducted their profession in Graeco-Roman times, as well as their training. Medical training was by way of apprenticeship with recognized doctors, but no qualifying examinations existed and the standard of practice thus varied enormously. Even in the Roman era the vast majority of medical doctors were Greek and in private practice as itinerant physicians. Civic doctors in the paid service of local communities appeared in Greek society from the $5^{\text {th }}$ century BC onwards, but much later in Rome - probably as late as the $4^{\text {th }}$ century AD. Rome's unique contributions to medicine lay in public health measures (e.g. their aqueducts, public baths and sewages systems) and an excellent medical service for their armies and navy. Hospitals (valetudinaria) were established for military purposes and for slaves on large Roman estates from the $1^{\text {st }}$ century BC, but civic hospitals for the general public originated as late as the $4^{\text {th }}$ century AD. The Greek medical schools of Cos and Cnidos were eventually superseded by the school of Alexandria in Egypt and towards the end of the Roman Empire by that of Carthage in northern Africa. Its gradual demise in the Christian era lowered the curtain on original medical endeavours during antiquity.

\section{Pre-classical Greece (before the $5^{\text {th }}$ Century BC)}

The roots of modern medicine can be traced back to the $5^{\text {th }}$ century $\mathrm{BC}$ when, together with the blossoming of literature, philosophy, arts and science during the Golden Age of Athens, the Greek communities at Cos and Cnidos laid the foundation of rational medicine. The Hippocratic corpus tells us much about the logic and ethics of the new medicine but little about the way in which practioners conducted their profession. In this article we examine the basics of medical practice in antiquity, and the teaching of influential doctors who led the way during Greek and Hellenistic times but also the subsequent Roman era.

Greek medical history goes back to Homeric times. In the Iliad (I.1-43ff; 450480 ; XI.518 and 833) the healing god
Apollo and his son, the physician, Asclepius, are involved in the Trojan war, as are Asclepius's sons (Machaon and Podaleirios) who are also doctors. Celsus (Proem. c.3) later observed that they were involved in treating battle wounds, but not in curing pestilential disease. The lliad does indeed mention 147 war wounds (106 spear thrusts, 17 sword slashes, 12 arrow wounds and 12 sling shot wounds) (Porter 1997:51).

Porter (1997:51) suggests that the Olympic Games (founded 776 BC) introduced a cult of pride in physique and physical fitness which had an effect on healthy living. There are conflicting views on the impact that ancient Egyptian medical heritage had on Greek medicine (Marganne 1993:35-43), which was practiced by a very heterogeneous community of "healers" (demiourgoi). 
The concept that disease was caused and controlled by the gods was generally accepted; religion and mantic influences thus played an overriding role. At this stage medicine was mainly in the hands of priests and magic healers, druggists and root cutters (rhizotomoi) (Godderis 1997:235-237). However, towards the $6^{\text {th }}$ century BC a group of philosopherphysicians came to the fore who significantly influenced the course of health care development. Among them was Thales of Miletus and his pupil Anaximander, followed by the remarkable Pythagoras (570-489 BC) from Croton in Southern Italy. Besides his enormous contributions in mathematics and physics, he (possibly in association with his pupil, Alcmaeon) formulated the theory of four body humours as the basis of human physiology - a theory, which although quite wrong, remained dogma for more than two millennia (Major 1954:110-116). It is evident that as early as the $6^{\text {th }}$ century $\mathrm{BC}$ there were centres of medical education at Croton, Cyrene (Northern Africa) and Cnidos (Nunn 1996:12).

The assertion made by the Greek historian, Diodorus Siculus (12.13.4), that as early as the $7^{\text {th }}$ century $\mathrm{BC}$ the state had already appointed salaried civic doctors, is not generally accepted (Nutton 1988:11), but Herodotus's claim (3.131ff.) that Democedes (one time reluctant court physician to the Persian King Darius) became a salaried doctor in Aegina in $530 \mathrm{BC}$ (later also in Athens and Samos) seems more credible (Nutton 1988:12). This was then possibly the first recorded example of physicians employed by the state to render a predetermined service to the populace.

\section{Classical Greece $\left(5^{\text {th }}\right.$ and $4^{\text {th }}$ Centuries BC)}

During the $5^{\text {th }}$ century $\mathrm{BC}$ and as part of the Golden age of Athens, a system of rational medicine (technê iatrikê) in which religion and supernatural factors played a minimal role was developed, mainly by the Greek medical fraternity on the island of Cos under the inspiration of Hippocrates. In this evolutionary process, earlier physicians like Anaxagoras and Empedocles made significant contributions (Major 1954:113-138). The gist of the new medicine was eventually formulated in the so-called Hippocratic Corpus consisting of approximately 70 books written by various authors from different parts of the Greek world, mostly completed by the $3^{\text {rd }}$ century $\mathrm{BC}$, but some added as late as the Christian era. Knowledge of anatomy was rudimentary, based largely on the anatomy of animals, and physiology was explained on the basis of four humours (white bile, black bile, blood, phlegm) which for good health, had to be in equilibrium with each other, but also with the four elements (earth, air, fire, water) and four "qualities" (heat, cold, dryness, dampness). Disease was explained as imbalances of this system, and although quite unscientific as measured by modern knowledge, it was nevertheless "rational" insofar as superstition and religion played a very small role in their argumentation (Retief \& Cilliers 2000:10-14). The admirable code of ethical conduct contained in the Corpus was never enforced on the profession, and we do indeed have ample evidence also of bad medicine practised by Greek physicians of the day (Hippocrates, Law c.1; Van der Eijk 1999:70-71). Public comment affirmed this, as well as satire in the theatre (Godderis 1997:249-250) and stinging criticism from philosophers like Plato, who condemned ignorant folk healers (Republic 364 b-c) as well as incompetent doctors (Charmides 156e). In the $4^{\text {th }}$ century BC the physician Diocles of Carystus, a pupil of Aristotle, contributed much to the Hippocratic tradition, but of his writings only a few fragments survived (Van der Eijk 1997:70). Aristotle and his Peripatetic School contributed extensively to medical knowledge (inter alia anatomy and embryology) (Major 1954:1390140).

The Hippocratic doctor treated patients from all sections of the community, although Godderis (1997:252-3) suggests that the rich probably received more attention than the poor. Training was acquired through apprenticeship to a physician - for the fortunate ones this happened at the schools of Cos and Cnidos. No professional registration was needed and training standards must have been extremely variable and inconsistent. Most physicians were men (iatroi) but there were also woman doctors (iatrinai), midwives (maiai) and even iatro-maiai. Nurses in the modern sense were unknown, but we read of assistants (huperetoi tôn iatrôn), usually slaves in training. Slaves could (and did) at a later stage also qualify as doctors; when ill, they were normally treated by huperetoi rather than iatroi (Krug 1993:194-5; Godderis 1997:251-3).

The bed-side approach recommended in the Hippocratic Corpus shows remarkable similarity to that of the modern doctor. In addition to extensive advice on appropriate dress, demeanour, even desirable physical features, the doctor is told that his assessment of the patient should be based on the proper use of his senses: observation, listening, smell and palpation. He must inform himself of all possibly relevant information, inter alia through discussions with relatives or friends. Examination of the patient would include observation of the patient's position in bed and general attitude, the breathing, condition of the abdomen, pulse (in Hippocratic times not yet an extensive science), chest (including auscultation with the ear against the thoracic wall: pleural rubs and succussion splashes were recognized), urine and other excreta. The overall assessment did not lead to a diagnosis, but to the formulation of a prognosis and appropriate treatment (to address the patient's assumed humoural imbalance). There were three levels of therapy, of which the first was dietetics, comprising not only dietary measures, but also procedures affecting life style like exercise and fitness programmes. When additional treatment was indicated, medicaments were prescribed. The third therapeutic level comprised surgery and cautery, which was only used as a last resort. However, the Hippocratic Corpus does contain extensive advice on aspects of surgery and orthopaedics in particular, and one gets the impression that the average physician was expected to handle all therapeutic modalities (Edelstein 1987:87-8, 91-102; Schlesinger 1999:9599). Diocles's prescriptions on dietetics and maintenance of normal health are so detailed and intricate that only the advantaged rich could afford such a life style. Plato (Republic 403e ff.) was quite critical about such regimes. The ethical code which accompanied Hippocratic medicine was an important conditioning factor in health care, containing classical admonishments such as: "Practice two things in your dealing with disease : try to help but do not harm the patient" (Epidemics 1:11). It is unsure what the precise role of the Hippocratic Oath was - it was almost certainly not taken by all qualifying doctors, and did not necessarily represent the common convictions of the times (Longrigg 
1998:105-6).

Hippocratic writings give little information about the nature of the professional organization or social details of doctor-patient contact. But from other contemporary writings, and Plato's works in particular, much can be learnt (Godderis 1997:233-273). In view of the heterogeneity of Greek physicians of this era it is very difficult to generalize about their status, public acceptability, even modes of practice. However, Edelstein (1987:87-90) suggests that the average Hippocratic doctor would probably have had an itinerant practice in search of a professional niche somewhere in the community. He would have been a craftsman rather than a professional as we know it, with limited status. His reputation would have been determined solely by his clinical successes, and he would have had to sell himself in competition with other doctors or healers. On arriving in a new city or town he would probably have hired accommodation in or near the market place, which would then serve as consulting rooms and living quarters. It would be quite in order for him to visit the consulting rooms of other doctors, to watch them examining their patients and to join in discussion of the case differing loudly with his colleague if he thought this might impress the patient or other people present. Being invited to visit a patient's home would be a bonus, and length of stay at a particular location would depend almost entirely on his patient load and acceptability to the community.

Salaried civic doctors in service of a local community existed from early times. Mention has already been made of the appointment of Democedes at Aegina in $530 \mathrm{BC}$. However, the next clear record of the appointments of civic doctors occurred in $440 \mathrm{BC}$ in Thurii, Southern Italy (at that stage colonized by Greek citizens). Subsequently civic doctors were appointed in most towns and cities of the Greek world. They were assured of a salary (at least initially) and additional perks, such as tax reduction, living accommodation, remuneration in kind (e.g. wheat), free entry to the theatre, and even statues in their honour. They were appointed by lay members of the ruling council, who regularly re-appraised them and could also discharge incompetent incumbents (although we have no real evidence of this ever happening). There was keen competition for these posts and we have evidence that doctors from Cosorigin were in demand (Nutton 1988:1114). Nutton also points out that precise, detailed information about their duties is strangely lacking. They were expected to render services free of charge to a component of the citizenry, but they could also charge fees. There is some evidence that during financial stringency, e.g. after defeat in the Peloponnesian War (late $5^{\text {th }}$ century BC), their stipends were withdrawn - but the posts remained in high demand and good civic doctors clearly enjoyed public respect and popularity.

The educated populace took great interest in matters medical, and there was no hard and fast differentiation between lay and medical literature - lay writers regularly wrote on medical issues. Matters of medical importance often featured in theatre plays and in discussions between physicians and knowledgeable non-medical individuals. It has indeed been suggested that the boundary between the selfacknowledged doctor and the educated layman was often narrow (Nutton 1988a:30-38).

\section{Hellenistic era ( $3^{\text {rd }}$ Century $\mathrm{BC}$ and later)}

The Hellenistic era following on Alexander the Great's conquests gradually merged into the Roman period. In 331 Alexandria was founded in the Nile delta and rapidly developed into a flourishing centre of cultural excellence under the influence of Greek kings (the Ptolemies).

Cos and Cnidos were now replaced by the Alexandrian school as the Mediterranean world's centre of medical excellence. Alexandria with its extraordinary museum and libraries, containing at its peak $400000-700000$ documents, consisting of papyrus and parchment rolls and codexes (McLeod 2004:5), attracted learned men from all over the Greek world - including poets, philosophers, scientists (e.g. Euclid and Archimedes) and physicians among whom Herophilus of Chalcedon and Erasistratus of Ceos were the most famous (Porter 1997:66-68; Major 1954:141-151). Herophilus was the first to dissect human cadavers (possibly even living convicts supplied by Ptolemy I and II) and so laid the foundation of anatomy. He also extended Hippocratic clinical medicine and wrote several major works specifically on anatomy (Von Staden 1994:1-88). Erasistratus built on Herophilus's anatomy and established a rational knowledge of physiology (the functioning of organs). In clinical medicine he was less impressive, but distinguished between therapeutics (iatrikê) and hygiene (hygieina), stressing the latter as more important in curing disease (Longrigg 1993:205-218). As from the $2^{\text {nd }}$ century $B C$ the Alexandrian school gradually split into factions consisting of the followers of Herophilus, Erasistratus and the Empiric school, and gradually lost its impact (Longrigg 1993:218-219). Although it had no formal system of teaching and offered no professional qualifications, the school upheld the best in Hippocratic medicine and produced discoveries which illuminated medical science for ten centuries (Major 1954:143). Its gradual demise in the Christian era lowered the curtain on progressive medical teaching and discovery during antiquity.

In this period Theophrastus of Ephesus (370-288 BC), student of Aristotle and his successor as head of the Lyceum (the famous school established by Aristotle in Athens), wrote one of history's first authoritative works on the value of plants and plant material in medicine (Major 1943:140).

The Dogmatic medical school, founded in the $4^{\text {th }}$ century BC by sons of Hippocrates, introduced speculation into medical practice - "where observation failed, reason might surprise". This underlay Alexandrian thinking, leading to the anatomical and physiological discoveries mentioned above. The Empiric school ( $3^{\text {rd }}$ century $B C$ ) was founded by a pupil (and eventual opponent) of Herophilus in protest against the growing impact of Alexandrian anatomy and physiology, claiming that this factual knowledge contributed little to actual healing of the sick. The Empirics favoured medicine based purely on experience and analysis of clinical cases (Major 1954:150-1).

The Asclepian cult of incubation sleep and temple healing, commencing at Epidaurus during the $4^{\text {th }}$ century BC, coexisted in harmony with Hippocratic medicine. It gradually spread through the Greek world and reached Rome in 293 BC, but was abolished as a pagan rite by early 
Christianity in the $4^{\text {th }}$ century $\mathrm{AD}$ (Major 1954:103-110).

The appointment of civic doctors mentioned above, continued, and from halfway through the $2^{\text {nd }}$ century $\mathrm{BC}$ they become known as archiatri. Rulers and even rich citizens commonly appointed personal physicians. Alexander the Great, for instance, was on his expeditions accompanied by full-time military doctors, and he also had a personal physician, Philippus (Krug 1993:204-5).

\section{The Roman era (up to the $3^{\text {rd }}$ Century AD)}

As early as the $4^{\text {th }}$ century BC Greek medicine started infiltrating Rome. Up till then traditional Roman medicine, very much like Greek medicine four to five centuries earlier, had been based on folk remedies, herbs, religious influences and superstition (Nutton 1988c:31-40). Although the Greek doctors were readily accepted by most Romans, there was also vicious resistance from certain leading figures. Cato the Elder (234-149 BC) in particular who had been treating his family, dependants and slaves with traditional remedies, cabbage and wine, was violently opposed to the Greeks, and even denied them access to his home (Nutton 1988b:42). Cicero (106-43 BC) considered doctors people of low standing - tradesman rather than gentleman. But paradoxically enough he had high praise for his own Greek physician (Nutton 1988a:28). Pliny the Elder (AD 23-79) launched a sustained, influential and potentially devastating attack on everything Greek and Greek medicine in particular, which he saw as causing progressive decline of Roman culture (Nutton 1988a:43). Greek doctors nevertheless proceeded to dominate the medical scene, and Nutton (1988b:37) estimates that more than $90 \%$ of Rome's doctors in the $1^{\text {st }}$ century AD were Greek, $75 \%$ in the $2^{\text {nd }}$ century and approximately $65 \%$ in the $3^{\text {rd }}$ century.

In order to practice in the Roman Empire, doctors only needed permission from the local magistrate. Julius Caesar welcomed Greek doctors, made them citizens and exempted them from tax. These concessions were upheld by subsequent emperors like Augustus, Vespasian and Hadrian. However, during the middle of the $2^{\text {nd }}$ century Antoninus Pius for financial reasons restricted the number of practitioners exempted in provincial centres to a maximum of 4,7 or 10 , depending on the size of town's population. In Rome all practitioners were tax exempted (Nutton 1988:15,18 and 19). Scarborough (1969:132) suggests that these doctors might even have been paid to treat the poor and to give medical instruction.

Among the healers of Rome counted large numbers of fringe healers, magicians, masseurs and druggists, in addition to recognized physicians, trained in apprenticeship with approved doctors. Unlike Greece there were no recognized centres of medical training, but there is some evidence that a Museum based on the Alexandrian model existed at Ephesus, associated with a group of physicians who organised academic activities (Scarborough 1969:132). Galen ( $2^{\text {nd }}$ century), critical of colleagues everywhere, was not impressed with medical standards in Rome (De methodo medendi 1.9-10). The incompetence of the medical profession was regularly lampooned in theatre and literature (Nutton 1988b:48-9), but Scarborough (1969:123-130, 135) illustrates the problem of generalizing about a very heterogeneous medical system which undoubtedly produced excellent as well as poor doctors. Total medicine undoubtedly included elements of astrology, magic, religion, folk traditions and superstition.

The majority of doctors (medici) were Greek migrants; there were also woman doctors (medicae) and midwives (obstetrices) (Jackson 1988:86-7). Rich families commonly had their private physicians. Emperors had full-time court physicians: Musa, a freed slave, served the emperor Augustus with great distinction; however, C. Stertinius Xenophon, as doctor at the court of Claudius, was suspected of conspiring to poison the emperor (Krug 1993:208210). Literature makes mention of a variety of specialists e.g. in eye diseases, ear disorders, women's conditions, hernias and anal complaints, fevers, dietetics and hydrotherapy. There were also dentists, and people specializing in eye diseases and in operations like trephination and lithotomy (Jackson 1988:113-126). Whether these persons were necessarily all regular doctors, is probable but not certain. Doctors were drawn from all layers of society, and even slaves could qualify themselves medically (Scarborough 1969:123-130,
135).

There is little information on the organization of medical practice, and it probably largely followed the Greek pattern. Nutton (1988b:30-46) argues that Pliny's severe criticism of Greek medicine in Rome was highly biased. Wealthy patients were seen at their homes while poorer patients visited the doctor at his consulting room, which was either at his home or in a taberna medica on the street, at a market place or even at the public baths. Druggists and other healers also worked from the taberna. It is probable that a large proportion of patients used "non-professional" treatment based on folk remedies as recorded in Pliny's writings and herbals prescribed by Dioscorides and others (Jackson 1986:6078). However, the standard clinical handling of patients, as recorded by Galen in particular, was based on the Hippocratic method. Examination of the patient led to a prognosis (not diagnosis). From this flowed an assumption (hupolêpsis) which after due evaluation would lead to a conclusion (epistêmê). Treatment followed which could consist of diet and lifestyle adjustment, medicaments or surgery. It was a time-consuming process (Horstmanshoff 1999:130-139).

Rome's original and unique contributions to health care are represented by their remarkable public health measures, as manifested mainly in construction of the massive Cloaca Maxima which initially drained the marshes of central Rome $\left(6^{\text {th }}\right.$ century BC) and later served as a sewer, and the building of aqueducts to supply the city with water. The first was constructed in $312 \mathrm{BC}$, and in $\mathrm{AD} 96$ there were 10 aqueducts; half of the water went to the public baths, which left about 50 gallons or 225 litres per person per day for a population of around 1,5 million (Major 1954:162-3).

Another unique achievement was Rome's efficient military health care system, established in the $1^{\text {st }}$ century BC. A team of full time doctors (mostly Greeks) called milites medici, accompanied the armies. They were supported by assistants (capsarii, named after the boxes of medical supplies they had to carry) whilst some soldiers (immunes) were given first aid training. In time the medici specialized as medici chirurgi or medici clinici. Veterinary surgeons cared for horses and other animals, and veterinary services 
were also available in the civic community (Scarborough 1969:171-2). In the fleet the full time doctors were called duplicarii they received double salaries because their task was considered more dangerous. Well-organized military hospitals (valetudinaria) were erected at strategic points on the Roman frontiers (Krug 1993:204-8). Although it is generally accepted that no civic valetudinaria for the general public existed at this stage, we have evidence that such hospitals were erected on large estates, primarily for the treatment of slaves (Columella XI.1.8; XII.3.8).

A number of sects or schools of medical theory arose in the Roman era, but their practical influence on the development of medicine was probably limited. The Methodist school ( $1^{\text {st }}$ century BC) taught that all diseases resulted from the abnormal functioning of minute body pores. Treatment to remedy this was considered simple and it was thus not necessary for a physician to have advanced knowledge of anatomy or physiology. In spite of their ridiculous theories, this sect did produce a number of able physicians. The Pneumatists ( $1^{\text {st }}$ century AD) based their theories on the importance of pneuma, a primitive vital spirit which controlled the body as part of the standard humoural theory. They were gradually absorbed by the Eclectic school which attempted to combine the best of the Empiric and Methodist schools; most of the significant physicians of the next five centuries supported this school (Major 1954:1689,1178-9).

Important medical personalities of the era included the following:

Asclepiades of Bithynia came to Rome in $91 \mathrm{BC}$ as an experienced Greek physician, who immediately impressed the capital with his strong personality and medical acumen. A controversial figure and a firm opponent of the Hippocratic humoural theories (he believed that health depended on proper functioning of bodily pores and atoms, anticipating the Methodist movement), he was criticised by inter alia Pliny the Elder and later castigated by Galen (Major 1954: 164-6).

Scribonius Largus, probably a Greek freedman of the $1^{\text {st }}$ century $\mathrm{AD}$, is best remembered for his extensive work on pharmaceutical recipes (Compositiones).
In the dedicatory letter prefacing this work he gave an excellent overview of contemporary medical ethics (Hamilton 1986:209-215). Dioscorides, an army surgeon of this period, wrote what was probably antiquity's best known pharmacopeia, the Materia Medica (AD 77).

Aretaeus of Cappadocia (a supporter of the Pneumatic school) was virtually unknown in his time, but through his published works posterity has recognized him as one of the best clinicians of the $2^{\text {nd }}$ century AD. A contemporary, Rufus of Ephesus, greatly impressed with his wide-ranging clinical contributions. Although little of his original works survived, Galen and later Arabic physicians quoted him profusely. Soranus of Ephesus ( $1{ }^{\text {st }}$ century AD) was the greatest gynaecologist and obstetrician of antiquity, but also contributed in other fields of medicine (Major 1954:179-188).

The encyclopedist, Cornelius Celsus wrote extensively on a wide variety of subjects and, like Pliny, was one of the few authors of the time to use Latin in stead of Greek. Although not medically qualified, his voluminous De medicina was an authoritative and objective summary of medical knowledge during the $1^{\text {st }}$ century $\mathrm{AD}$, and is still admired today (Major 1954:169-172).

But the giant of Roman medicine was undoubtedly the Greek, Galen. Major (1954:188-202) rightly states that no physician, before or since, has exercised so great an influence on medical history. An ardent admirer of Hippocratic medicine, he wrote extensively on science, philosophy and law, in addition to medicine. His exaent medical writings comprise close on two and a half million words, and in the course of time at least half as many more were lost to posterity. Although strictly rational in his approach, Galen paid more heed to the significance of dreams, visions and amulets in medicine than did his Hippocratic forebears. He believed in an all-powerful monotheistic god, and though not a Christian, his views on many aspects were accepted as dogma by the Christian church through the Middle Ages.

\section{Twilight of the Roman empire}

From the late $3^{\text {rd }}$ century up to the fall of
Rome in 476, medical science showed little development. In fact, Nutton describes the medical writers of this period as "the medical refrigerators of antiquity" (1984:2), since most of them merely produced compilations and translations of the ancient Greek authorities. It was, however, a crucial period in the transmission of medical texts knowledge of Greek was dwindling, and thanks to these medical writers the contents of the works of ancient Greek authorities were preserved for posterity. Equally important, this medical knowledge was disseminated to laymen for self-help due to increasing complaints about the lack of expertise of doctors.

The main centre for medical knowledge after Alexandria now shifted to refounded Carthage in North Africa, which experienced a flowering of scientific and especially medical activity in especially the late $4^{\text {th }}$ century AD. Between c. 370 and $450 \mathrm{AD}$ a number of doctors/medical authors/translators/adaptors of medical works were active, to such an extent that Sabbah (1998:132) even refers to an "African School". The founder, as it were, of this "school" was Helvius Vindicianus, a distinguished physician, who in 368 was appointed by the emperor Valentinian I as Count of the newly established College of Physicians in Rome, and in 380/1 became Proconsul of the Roman province of North Africa. Unfortunately few of his works have survived, and we have little knowledge of his practice as doctor apart from enthusiastic praise by various of his students and acquaintances. Theodorus Priscianus was one of these students; his book, the Euporista (literally "easily obtainable [remedies]"), was very popular during the Middle Ages. Cassius Felix also came from Roman Africa, and is known for a short handbook, the De medicina, dedicated to his son in 447 , containing valuable advice derived from the ancient Greeks on all kinds if diseases. Of Caelius Aurelianus, probably a contemporary of Cassius Felix, three works survived, two of which are Latin translations of Greek works of Soranus of Ephesus. Caelius's book, On acute and chronic diseases, is an important account of all aspects, theoretical and practical, of pathology and therapeutics as known and applied in his time.

The elite College of Physicians mentioned above originally consisted of 14 members, who would then elect, on 
strict merit and by majority vote, future physicians as needed. Appointments were ratified and probably supervised by the emperor. This is the first instance where medical doctors were selected on medical grounds by peers and not by lay members of the public. The College, however, had no mandate to ensure acceptable professional conduct. These doctors were held in high regard and received commoda annonaria (payment in kind), possibly in addition to a salary. They were exempted of tax and allowed to charge private fees to the wealthy, but the emperor's request was that free service to the poor should receive preference. To what extent this happened is unclear. The system was ratified by Valentinian II in 387 (Nutton 1988:19-21).

Civic hospitals as we know them, originated in the course of the $4^{\text {th }}$ century AD. Under Christian influence hospices (called xenodochia in the mainly Greekspeaking East), initially erected to shelter pilgrims and messengers traveling between various bishopries, later came to house disadvantaged people, as well as the ill and mentally infirm. They gradually developed into hospitals, and also spread to the west when the emperor Julian the Apostate (361-363), in an attempt to revive paganism, tried to attract converts by establishing xenodochia in every city. A century later the emperors Leo and Anthemius confirmed this policy (Cilliers \& Retief 2002).

Although civic doctors serving a specific community had been operating in Greek cities for five centuries, Nutton (1988:19) states that Rome appointed its first civic doctors only in AD 368. This delayed appointment of civic doctors might partially have been due to an unfortunate experience with the appointment of a Peloponnesian doctor as first civic doctor to Rome in $219 \mathrm{BC}$. This person, Archagathus, was enthusiastically welcomed and given a consulting room in the city, but according to Pliny (Naturalis Historia 29.6.12 ff) he was so cruel and incompetent that the city soon discharged him and refrained from repeating the experiment.

Early Christianity's strictly religious approach to illness brought potential for conflict with Hippocrates's rational medicine. However, while the first centuries AD brought quite severe persecution from the Roman authorities, Christians had no real problems with rational/secular physicians. When Christianity was elevated to state religion in the $4^{\text {th }}$ century and the Church became very powerful, they proceeded to dominate most facets of civil society, including the art of medicine, which had a negative effect on all scientific advancement and medicine in particular (Retief \& Cilliers 2001:61-73).

\section{Conclusion}

The period covered in this study represents a thousand years of development and consolidation of the science and practice of medicine. It is a story of remarkable Greek innovation and original thought, consolidated by solid practical contributions from the Romans, resulting in a system of medicine which was subsequently able to withstand a millennium of scientific stagnation. Although it was the erudition, dogma and authority of Galen which ruled supreme in Medieval times, much of his theory was disproved by new knowledge emanating from the Renaissance. The simple clinical guidelines and ethos of Hippocrates, on the other hand, withstood the test of time much better and is today still quoted with reverence.

\section{References}

CELSUS, 1935: On Medicine. Loeb Classical Library Vol. 1. Transl. W.G. Spencer. Cambridge, MA: Harvard University Press.

COLUMELLA, 1955: On Agriculture. Loeb Classical Library Vol. III. Transl. E.S. Forster. Cambridge, MA: Harvard University Press.

DIODORUS SICULUS, 1946: Library of History. Loeb Classical Library Vol. 1. Transl.C.H. Oldfather. Cambriodge, MA: Harvard University Press.

DIOSCORIDES, 2000: De Materia Medica. Being a Herbal with Many Other Medicinal Materials. Transl. TA. Osbaldeston \& R.P.A. Wood.

EDELSTEIN, L 1987: The Hippocratic Physician. In: O. \& C.H. Temkin (edd.). Ancient Medicine. Baltimore: John Hopkins University Press.

HAMILTON, J S 1986: Scribonius Largus on the Medical Profession. Bull. Hist. Medicine, 60:209-215.

GODDERIS, J 1997: De Beste Arts zij ook een Filosoof? Peeters.

HOMER, 1924: Iliad. Loeb Classical Library Vol. 1. Transl. A.T. Murray. Cambridge, MA: Harvard University Press.

HERODOTUS, 1921: The Persian Wars. Loeb Classical Library. Transl. A.D. Godley. Cambridge, MA: Harvard University Press.

HIPPOCRATES, 1923: Law et al. Loeb Classical Library Vol. II. Transl. W.H.S Jones. Cambridge, MA: Harvard University Press.

HORSTMANSHOFF M, 1999: Hoe ging Galenus met zijn patiënten om? Hermeneus. 17.2: 130-139.

JACKSON, R 1988: Doctors and Diseases of the Roman Empire. Norman \& London: University of Oklahoma Press.

KRUG, A 1993: Heilkunst und Heilkult. München: Verlag C.H. Beck.

LONGRIGG, J 1998: Greek Medicine. From the Heroic to the Hellenistic Ages. London: Duckworth.

LONGRIGG, J 1993: Greek Rational Medicine. London: Routledge.

MARGANNE M, H 1993: Links Between Egyptian and Greek Medicine. Forum. $3.5: 35-43$

MCLEOD, R 2004: Introduction: Alexandria in History and Myth. In: R. McLeod (ed.), The Library of Alexandria. London: I. B. Taurus.

MAJOR, RH 1954: A History of Medicine. Springfield: Charles Thomas Publ.

NUNN, JF 1996: Ancient Egyptian Medicine. Norman: University of Oklahoma Press.

NUTTON, V 1984: From Galen to Alexander. Aspects of Medicine and Medical Practice in Late Antiquity. Dumbarton Oaks Papers. 38: 1-14.

NUTTON, V 1988: Continuity or Rediscovery? The City Physician in Classical Antiquity and Medieval Italy. In: From Democedes to Harvey: Studies in the History of Medicine. London: 
Variorum Reprints.

NUTTON, V 1988a: Murders and Miracles. Lay Attitudes towards Medicine in Classical Antiquity. In: From Democedes to Harvey: Studies in the History of Medicine. London: Variorum Reprints.

NUTTON, V 1988b: The Perils of Patriotism. Pliny and Roman Medicine. In: From Democedes to Harvey: Studies in the History of Medicine. London: Variorum Reprints.

PLATO, 1930: The Republic. Loeb Classical Library Vol. 1V. Transl. P. Shorey. Cambridge, MA: Harvard University Press.

PLATO, 1926: Charmides et al. Loeb Classical Library Vol. XII. Transl. W.R.M. Lamb. Cambridge, MA: Harvard University Press.

PLINY, 1963: Natural History. Loeb Classical Library Vol. VIII. Transl. W.H. S. Jones. Cambridge, MA: Harvard University Press.

PORTER, R 1997: The greatest benefit to mankind. London: Harper Collins Publ.

RETIEF, FP \& CILLIERS, L 2000: Hippokrates: Feit en Fiksie. Geneeskunde. 42.10:10-14.

RETIEF, FP \& CILLIERS, L 2001: The Influence of Christianity on GraecoRoman Medicine up to the Renaissance. Akroterion. 46:61-73.

SABBAH, G 1998: Notes sur les auteurs médicaux africains de l'Antiquité tardive ( $\mathrm{IV}^{\mathrm{e}}-\mathrm{V}^{\mathfrak{c}}$ siècles). In: Recherches et Travaux. Curiosité historique et intérêt philologiques 54:131-150.

SCARBOROUGH, J 1969: Roman Medicine. London: Thames \& Hudson.

SCHLESINGER, FG 1999: De diagnostische middelen van de arts in die Grieks-Romeinse traditie. Hermeneus. 71.2:95-99.

VAN DER EIJK, PJ 1999: Helpen of niet schaden. Hermeneus. 71.2:70-71.

VON STADEN, H 1994: Herophilus. The Art of Medicine in Early Alexandria. Cambridge University Press. 